\title{
CDI33 expression is correlated with lymph node metastasis and vascular endothelial growth factor-C expression in pancreatic cancer
}

\author{
S Maeda' ${ }^{1,3}$, H Shinchi', H Kurahara', Y Mataki', K Maemura', M Sato' ${ }^{2}$ S Natsugoe', T Aikou' and S Takao ${ }^{*, 2,3}$ \\ 'Department of Surgical Oncology and Digestive Surgery, Field of Oncology, Course of Advanced Therapeutics, Kagoshima University Graduate School of \\ Medical and Dental Science, 8-35-I Sakuragaoka, Kagoshima 890-8520, Japan; ${ }^{2}$ Frontier Science Research Center, Kagoshima University, Faculty of \\ Medicine, 8-35-I Sakuragaoka, Kagoshima 890-8520, Japan
}

\begin{abstract}
Although CDI 33 has been shown to be a marker for cancer stem cells in various tumours, its expression in pancreatic cancer has not yet been clinically reported. In this study, we investigated the relationship between CDI33 expression and clinicopathological factors in pancreatic cancer. Pancreatic head carcinoma specimens from 80 patients who underwent surgical resection were immunohistochemically assessed for CDI33, vascular endothelial growth factor (VEGF)-C, CXCR4, CD34, Ki-67, and cytokeratin (CK) expressions. Sixty percentage (48/80) of specimens were CDI33-positive, with less than I5\% cells per specimen expressing the marker. CDI33-positive cells were found at the peripheral site of adenocarcinoma glandular structures and were negative for CK. There was a significant correlation between CDI33 expression and clinicopathological factors, including histological type, lymphatic invasion, and lymph node metastasis $(P=0.0215,0.0023$, and 0.0024 , respectively). Vascular endothelial growth factor-C expression was also significantly correlated with CDI33 expression $(P=0.0002)$. Consequently, the 5-year survival rate of CDI33-positive patients was significantly lower than that of CDI33-negative patients $(P=0.0002)$ and multivariate analysis revealed that CDI33 expression was an independent prognostic factor $(P=0.0103)$. These results suggest that $C D I 33$ expression in pancreatic cancer was significantly associated with lymphatic metastasis, VEGF-C expression, and prognosis.

British Journal of Cancer (2008) 98, I389-1397. doi:I0.1038/sj.bjc.6604307 www.bjcancer.com

Published online 18 March 2008

(c) 2008 Cancer Research UK
\end{abstract}

Keywords: pancreatic cancer; cancer stem cell; CDI33; lymph node metastasis; VEGF-C; predicting factor

Pancreatic adenocarcinoma patient survival rates are lower than those of other forms of gastrointestinal malignancies (Silverberg and Lubera, 1988). This could be because of the propensity for early metastasis to regional lymph nodes and the liver, as the presence or absence of lymph node metastasis is an important prognostic factor for patients with pancreatic cancer (Maeda et al, 2007).

The existence of cancer stem cells (CSCs) was first demonstrated by transplantation of a small population of harvested leukaemia cells from patients into immunedeficient mice, which then developed the same cancer (Bonnet and Dick, 1997). Since then, recent evidence suggests that a subset of cells within a tumour has stem-like characteristics, including the ability to initiate tumours, high proliferative rates, a high capacity of self-renewal, and the propensity to differentiate into actively proliferating tumour cells (Reya et al, 2001; Presnell et al, 2002; Pardal et al, 2003). These stem-like tumour cells are often associated with elevated expression of the stem cell surface marker CD133 (Neuzil et al, 2007).

CD133 (AC133) is a highly conserved antigen and the human homologue of mouse Prominin-1, which was originally identified as a 5-transmembrane cell surface glycoprotein expressed in a subpopulation of CD34+ haematopoietic stem and progenitor cells

\footnotetext{
*Correspondence: Dr S Takao;

E-mail: sonshin@m2.kufm.kagoshima-u.ac.jp

${ }^{3}$ These authors contributed equally to this work.

Revised 2 January 2008; accepted I I February 2008; published online I8 March 2008
}

derived from human fetal liver and bone marrow (Miraglia et al, 1997; Yin et al, 1997). CD133 expression has been detected in several normal tissues including neuroepithelium, embryonic and adult immature epithelia (Weigmann et al, 1997; Corbeil et al, 2000; Richardson et al, 2004; Shmelkov et al, 2005). The association between CD133 and CSCs has been documented in haematological malignancies (Horn et al, 1999) and since then, CD133 expression has been identified in various types of solid tumours, including brain tumours (Singh et al, 2003, 2004; Beier et al, 2007), prostate cancer (Collins et al, 2005), kidney cancer (Florek et al, 2005), melanoma (Klein et al, 2007; Monzani et al, 2007), ovarian cancer (Ferrandina et al, 2007), hepatocellular carcinoma (Suetsugu et al, 2006; Ma et al, 2007; Yin et al, 2007), and colon cancer (Ieta et al, 2007; O'Brien et al, 2007; Ricci-Vitiani et al, 2007).

Transplantation experiments have clearly shown that the behaviour of CD133-positive cancer cells differs from that of CD133-negative cancer cells. For example, transplantation of as few as $100 \mathrm{CD} 133^{+}$glioblastoma cells successfully induced tumours in immunodeficient mice, whereas transplantation of $1 \times 10^{5} \mathrm{CD}_{133^{-}}$cells isolated from the same tumour failed to do so (Singh et al, 2004). Moreover, $\mathrm{CD} 133^{+}$and $\mathrm{CD} 133^{-}$glioblastomaderived cells showed differential growth characteristics and molecular profiles (Beier et al, 2007). $\mathrm{CD}_{133^{+}}$cancer cells of glioma exhibited resistance to radiation (Bao et al, 2006a). In prostate cancer, a CSC population with the $\mathrm{CD} 44^{+} /$integrin $\alpha 2 \beta 1^{\text {hi }}$ / $\mathrm{CD}_{133^{+}}$phenotype has been identified that exhibits extensive proliferation, self-renewal, differentiation, and invasion (Collins et al, 2005). In colon cancer, a small number of $\mathrm{CD}_{133^{+}}$cells can 
maintain themselves as well as differentiate and re-establish tumour heterogeneity after serial transplantation (O'Brien et al, 2007; Ricci-Vitiani et al, 2007). $\mathrm{CD}_{133^{+}}$cells in colon cancer cell lines have a high degree of tumorigenic ability in vivo, and their levels of proliferation, colony formation, and invasive ability were found to be higher than those of $\mathrm{CD}_{133^{-}}$cells in vitro (Ieta et al, 2007). There are also small populations of $\mathrm{CD}_{133^{+}}$cells in human hepatocellular carcinoma (HCC) cell lines and primary HCC tissues (Yin et al, 2007). In contrast with these findings, it was reported that as many as half of Huh-7 cells, a human liver cancer cell line, are $\mathrm{CD}_{133^{+}}$(Suetsugu et al, 2006). The $\mathrm{CD}_{133^{+}}$cells possess a greater colony-forming efficiency, higher proliferative output, and greater ability to form tumour in vivo (Ma et al, 2007). Elevated CD133 expression was found in two of five pancreatic carcinoma cell lines (Olempska et al, 2007). Furthermore, a recent report demonstrated that a subpopulation of $\mathrm{CD} 133^{+} \mathrm{CXCR} 4^{+}$ cells was responsible for tumour metastasis (Hermann et al, 2007).

CD133 mRNA expression appears to be an independent prognostic factor for overall survival, as increased levels were detected in the peripheral blood of cancer patients with bone metastasis (Mehra etal, 2006) and were shown to predict colon cancer recurrence (Lin et al, 2007). Tumorigenic cells display unique surface marker patterns, such as $\mathrm{CD} 44^{+}$in head and neck squamous cell carcinoma (Prince et al, 2007), epithelial cell adhesion molecule (EPCAM) ${ }^{\text {high }} \mathrm{CD} 44^{+}$in colon cancer (Dalerba et al, 2007), $\mathrm{CD} 44^{+}$integrin $\alpha 2 \beta 1^{+}$in prostate cancer cells (Patrawala et al, 2007), CD44 ${ }^{+} \mathrm{CD} 24^{- \text {low }}$ epithelial-specific antigen (ESA) ${ }^{+}$(Al-Hajj et al, 2003), CD44 ${ }^{+}$CD24-llow (Ponti et al, 2005) in breast cancer associated with distant metastasis (Abraham et al, 2005), and $\mathrm{CD} 44^{+} \mathrm{CD} 24^{+} \mathrm{ESA}^{+}$in pancreatic cancer (Li et al, 2007).

However, the possible clinical significance of CD133 expression in pancreatic cancer has not been investigated using immunohistochemistry, which is considered a difficult technique because of the inability to detect small numbers of putative stem cells (Miki et al, 2007). Nevertheless, immunostained cells may reflect the original features of cells in the tissue, so we used this approach in the present study to detect CD133-positive cells in paraffinembedded specimens from pancreatic cancer patients. CD133positive sections were also subjected to analysis of vascular endothelial growth factor (VEGF)-C expression. The purpose of this study was (i) to examine the expression of CD133 in surgical specimens of pancreatic head carcinoma by immunohistochemical methods, (ii) to explore possible correlation between CD133 expression and clinicopathological variables, (iii) to correlate expression of CD133 with VEGF-C, and (iv) to determine the prognostic value of CD133 expression.

\section{MATERIALS AND METHODS}

\section{Patients and specimens}

Eighty patients (52 male and 28 female) who underwent surgical treatment at Kagoshima University Hospital, Kagoshima, Japan for invasive ductal adenocarcinoma of the pancreatic head were included in the study. The patient age range was 42-80 years (mean 66.0 years). All patients underwent macroscopically curative resection by total pancreatectomy, pancreaticoduodenectomy, or pylorus-preserving pancreaticoduodenectomy with lymph node dissection. No preoperative chemotherapy or radiotherapy was administered. Cancer tissue specimens were collected from the patients after informed consent had been obtained, in accordance with the institutional guidelines of our hospital. The number of patients with pT1, pT2, pT3, and pT4 tumours was three $(3.8 \%)$, four $(5.0 \%), 65(81.3 \%)$, and eight $(10.0 \%)$, respectively.

Resected primary tumours and lymph nodes were histologically examined by haematoxylin and eosin staining using the tumour-node-metastasis classification system (Sobin and
Wittekind, 2002). Histologically, all of the tumours were invasive ductal adenocarcinomas (35 well differentiated, 42 moderately differentiated, and three poorly differentiated). Lymphatic and venous invasions were observed in $69(86.3 \%)$ and 61 tumours (76.3\%), respectively. Lymph node metastasis was present in 51 tumours $(63.8 \%)$.

All patients were assessed by radiography, ultrasonography, and computed tomography every 3 months after discharge. New lesions detected by imaging were considered indicative of relapse. The median follow-up period was 20 months (range 6-168 months). During this period, 29 patients experienced recurrence of liver disease $(36.3 \%)$.

\section{Immunohistochemistry}

Primary lesions were fixed in $10 \%$ formaldehyde, embedded in paraffin, and cut into five $3-\mu \mathrm{m}$ thick sections every $30 \mu \mathrm{m}$. Sections were deparaffinised in xylene, rehydrated in a graded series of ethanol, and incubated in $3.0 \%$ hydrogen peroxide in methanol for $10 \mathrm{~min}$ to block endogenous peroxidase action. Slides were heated at $100^{\circ} \mathrm{C}$ in a microwave oven in 10 mm sodium citrate $(\mathrm{pH}$ 6.0) for $10 \mathrm{~min}$ and cooled to room temperature. After incubation in $1 \%$ bovine serum albumin for $30 \mathrm{~min}$ at room temperature, sections were incubated overnight at $4{ }^{\circ} \mathrm{C}$ with an anti-CD133 goat polyclonal antibody (Santa Cruz Laboratory, Santa Cruz, CA, USA; diluted $1: 200$ in phosphate-buffered saline (PBS)), anti-VEGF-C goat polyclonal antibody (Santa Cruz Laboratory; diluted $1: 200$ in PBS), anti-CXCR4 mouse monoclonal antibody (R\&D Systems, Minneapolis, MN, USA; diluted 1:200 in $\mathrm{PBS}$ ), and anti-CD34 mouse monoclonal antibody (DAKO Corporation, Carpinteria, CA, USA; diluted 1:100 in PBS) for immunostaining microvessels.

The $3-\mu \mathrm{m}$ thick paraffin sections of primary tumours were deparaffinised, treated with the heat-induced antigen retrieval technique, and epithelial pancreatic carcinoma cells were immunostained for $60 \mathrm{~min}$ using cytokeratin (CK) AE1/AE3 (20:1 ratio of $A E 1$ to AE3, DAKO Corporation; diluted $1: 200$ in PBS), a mouse monoclonal antibody cocktail that reacts with all epithelial cells of normal pancreatic duct and tumour cells (Pasquinelli et al, 1995; Kurahara et al, 2007), and Ki-67 mouse monoclonal antibody (DAKO Corporation; diluted $1: 50$ in PBS) that reacts with proliferating cells at any phase of the cell cycle (except for G0 phase) (Igarashi et al, 1999). Reactions were developed using the avidin-biotin immunoperoxidase technique (ABC method; Hsu et al, 1981). Immunoreactivity was visualised using the Vectastain Elite $\mathrm{ABC}$ kit and a 3,3'-diaminobenzidine solution (Vector Laboratories Inc., Burlingame, CA, USA). Sections were then briefly counterstained with haematoxylin.

All immunostained slides were inspected by two independent observers (SM and ST), who had no prior knowledge of the clinicopathological findings. Ten fields (inside the tumour and in the area exhibiting tumour invasion) were selected, and expression was evaluated in 1000 tumour cells (100 cells per field) with highpower $(\times 200)$ microscopy. Specimens were defined as positive for CD133 expression if there were tumour cells distinctly stained by anti-CD133 antibody. The presence of VEGF-C and CXCR4 immunoreactivity in over $10 \%$ of tumour cells was defined as positive expression. Immunostaining for CD34 was assessed to determine microvessel density (MVD) (Weidner et al, 1991; Maeda et al, 2007; Mohammed et al, 2007). Vessels in the five most highly visualised areas $\left(0.785 \mathrm{~mm}^{2}\right.$ per field) by CD34 immunostaining were counted under a $\times 200$ light microscope. The tumour MVD was calculated as the mean value of five fields.

\section{Statistical analyses}

Group differences were statistically analysed using the $\chi^{2}$ test and $t$-test. The Kaplan-Meier method was used to analyse survival, 

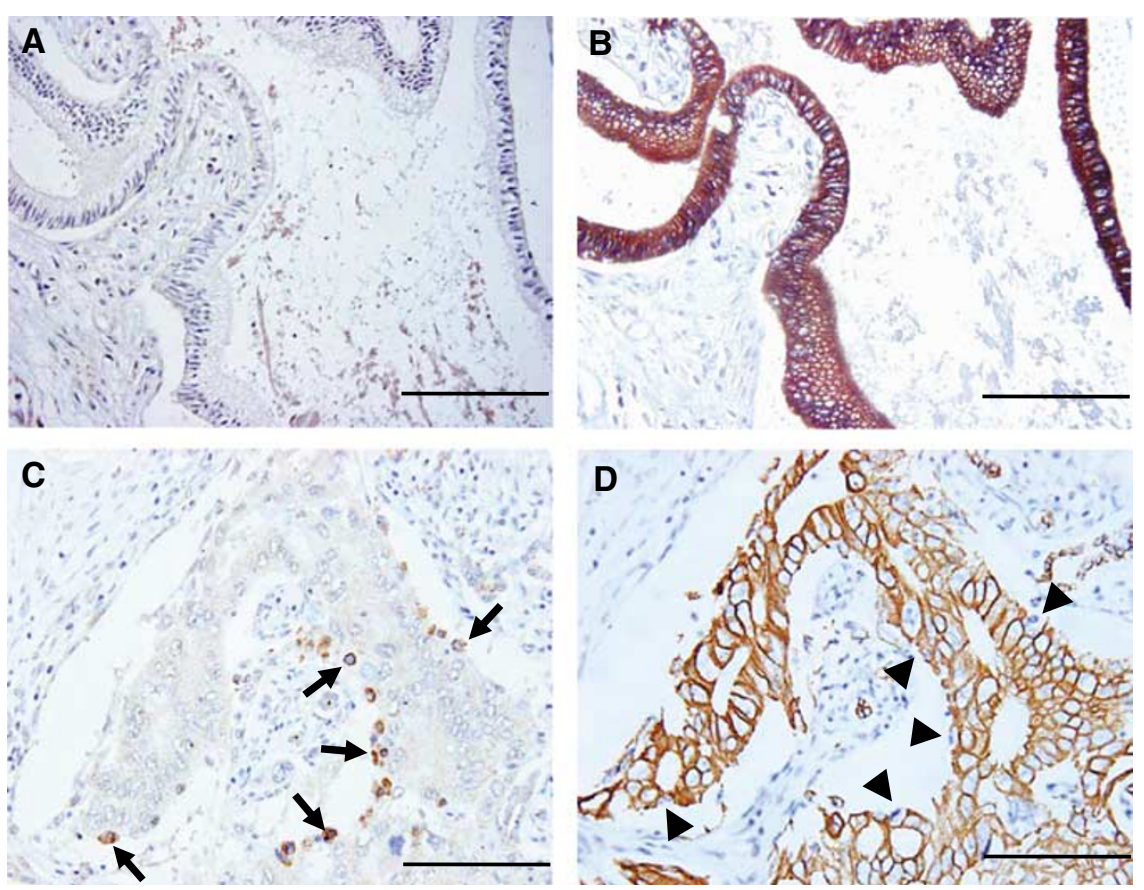

Figure I Immunohistochemical staining for CDI33 and CK in invasive ductal adenocarcinoma of the pancreas head. (A) Normal pancreatic ductal epithelium cells were not stained for CD I33. (B) The ductal epithelium cells in the consecutive slices of (A) were clearly stained by CK antibody. (C) CDI33 expression appeared to be present at the peripheral portions (facing the interstitial space) of the glandular structures of adenocarcinoma. The percentage of immunoreactive cells (arrows) was estimated to be less than $5 \%$ of the tumour cells. (D) The CK antibody clearly reacted with the CDI33negative cells of adenocarcinoma, but not with the CDI33-positive cells (arrowheads) in the consecutive slices of $(\mathbf{C})$. Scale bars, I00 $\mu$ m.
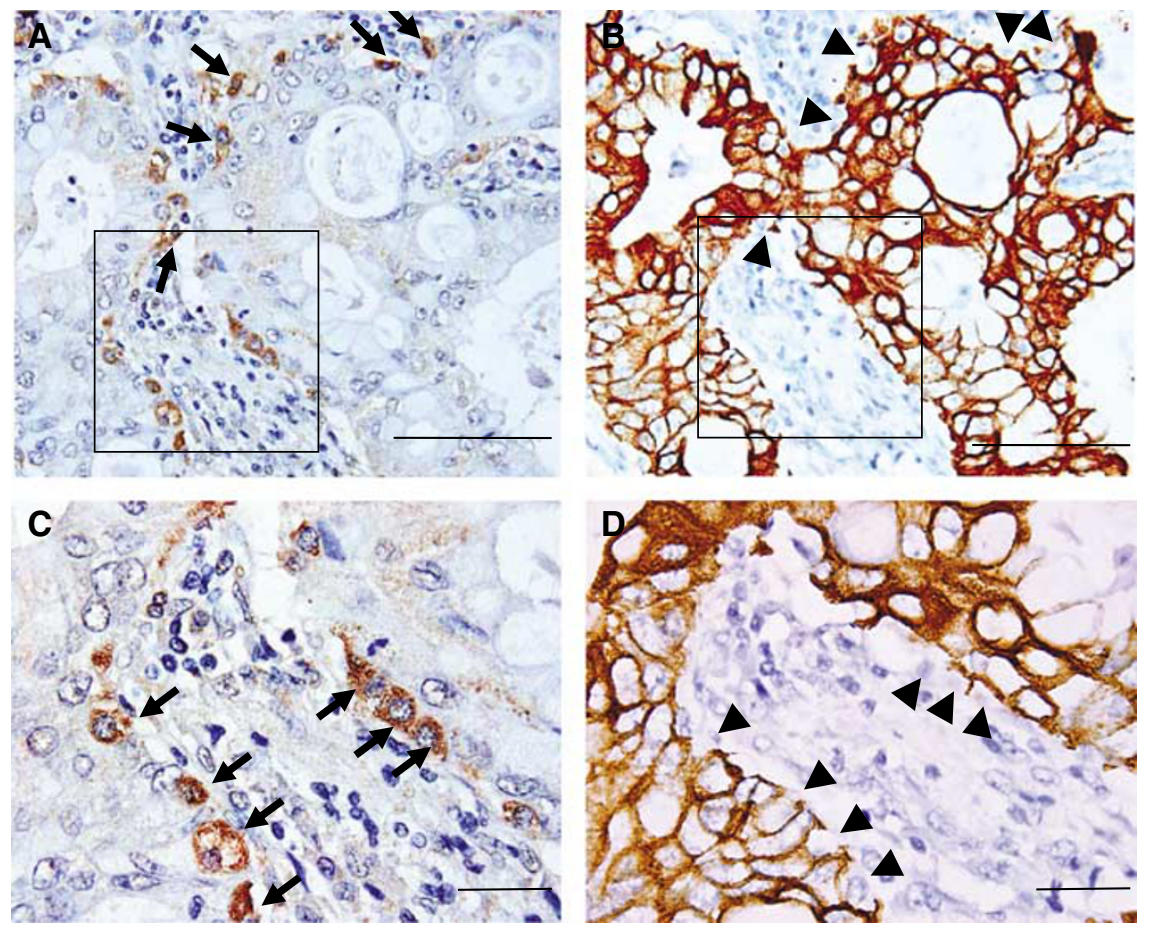

Figure 2 (A) CDI33 expression (arrows) appeared to be present in the peripheral portions of the glandular structures. The percentage of immunoreactive cells (arrows) was estimated to be more than $5 \%$ of the tumour cells. (B) The CK antibody clearly reacted with the CDI 33-negative cells of adenocarcinoma, but not with the CDI33-positive cells (arrowheads) in the consecutive slices of $(\mathbf{A})$. (C) CDI33 expression was observed mainly in the cytoplasm of tumour cells (arrows). Shown is a magnified figure described in $(\mathbf{A}$ ) as a box. (D) CDI33-positive cells were unreactive with the CK antibody (arrowheads) in the consecutive slices of (C). Shown is a magnified figure described in (B) as a box. Scale bars, I00 $\mu \mathrm{m}(\mathbf{A}$ and $\mathbf{B}), 20 \mu \mathrm{m}(\mathbf{C}$ and $\mathbf{D})$.

and the log-rank test was used to estimate differences in survival. Prognostic factors were examined using univariate and multivariate analyses (Cox proportional hazards regression model).
$P$-values less than 0.05 were considered statistically significant. All statistical analyses were performed using StatView statistical software version 5.0 (SAS Institute Inc., Cary, NC, USA). 


\section{RESULTS}

Expression of CD133 and CK in pancreatic head carcinoma specimens

No CD133 immunoreactivity was observed in normal pancreatic ductal epithelium (Figure 1A), which was clearly stained by the CK antibody (Figure 1B). CD133-positive tumour cells were present in the peripheral site (facing interstitial space) of adenocarcinoma glandular structures in patient samples with both less than (Figure 1C, arrows) and more than 5\% CD133-positive tumour cells (Figure 2A, arrows). CD133-negative cells of adenocarcinoma were CK-positive, but CD133-positive cells were not (Figure 1D, arrowheads; Figure $2 \mathrm{~B}$ and $\mathrm{D}$, arrowheads), which is consistent with previous findings (Hermann et al, 2007). Notably, positive CD133 expression was observed in the cytoplasm of carcinoma cells (Figure 2C, arrows).

CD133 expression was classified into five levels: negative (0\%), less than 5,5-10,11-15, and more than $15 \%$ (Figure 3). Fortyeight $(60.0 \%)$ of 80 specimens were CD133-positive and the percentage of CD133-positive cells per specimen was less than $15 \%$ (Figure 3).

\section{Correlation between CD133 expression and clinicopathological factors}

As shown in Table 1, CD133 expression was significantly correlated with clinicopathological parameters, including histological type $(P=0.0215)$, lymphatic invasion $(P=0.0023)$, and lymph node metastasis $(P=0.0024)$. However, there was no significant association between CD133 expression and age, gender, tumour depth, cancer stage, venous invasion, or liver metastasis (Table 1).

\section{Relationship between CD133 and VEGF-C expression}

When we correlated expression of CD133 with VEGF-C in pancreatic cancers, we observed a significant association between CD133 expression and VEGF-C expression $(P=0.0002$; Table 2$)$. In Figure $4 \mathrm{~A}$, a typical pattern of VEGF-C-positive expression is shown as an example in the consecutive slices of Figure 1C.

\section{Relationship between CD133 and CXCR4 expression}

We next examined the correlation between CD133 and CXCR4 expression as it was recently demonstrated that $\mathrm{CD} 133^{+} \mathrm{CXCR}^{+}$ cells are involved in tumour metastasis (Hermann et al, 2007). Eighty-five percentage ( 68 out of 80 ) of specimens tested exhibited positive expression for CXCR4. Notably, positive expression of CXCR4 was observed in all epithelial cells of adenocarcinoma. In

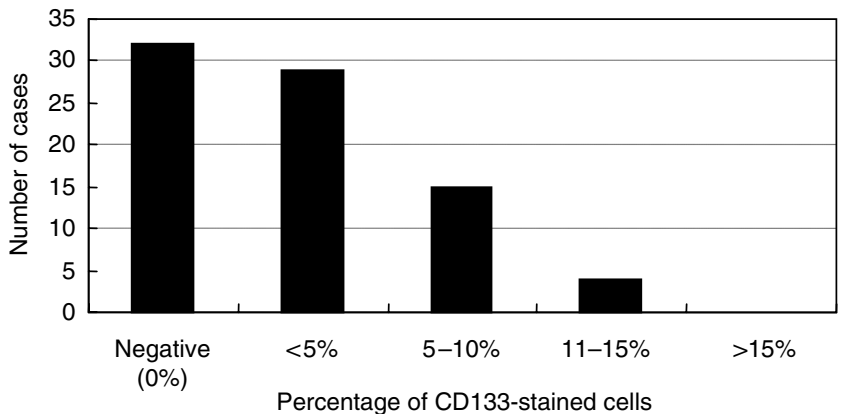

Figure 3 Classification of CDI33-positive expression in the invasive ductal adenocarcinoma of the pancreas head samples from 80 patients. Tumour samples were classified into five groups (negative $(0 \%),<5,5-10$, II -15 , and $>15 \%$ ) based on the percentage of stained cells.
Table I Correlation between CDI33 expression and clinicopathologic factors in pancreatic head carcinoma

\begin{tabular}{|c|c|c|c|c|}
\hline & \multirow[b]{2}{*}{$\begin{array}{l}\text { Total } \\
n=80 \text { (\%) }\end{array}$} & \multicolumn{2}{|c|}{ CDI33 expression } & \multirow[b]{2}{*}{$P$-value } \\
\hline & & $\begin{array}{l}\text { Positive } \\
n=48 \\
60.0 \%\end{array}$ & $\begin{array}{l}\text { Negative } \\
n=32 \\
40.0 \%\end{array}$ & \\
\hline \multicolumn{5}{|l|}{ Age (years) } \\
\hline Mean \pm s.d. & & $65.5 \pm 9.9$ & $66.8 \pm 8.8$ & 0.6908 \\
\hline \multicolumn{5}{|l|}{ Gender } \\
\hline Male & $52(65.0)$ & $34(70.8)$ & $18(56.3)$ & \multirow[t]{2}{*}{0.1803} \\
\hline Female & $28(35.0)$ & $14(29.2)$ & $14(43.8)$ & \\
\hline \multicolumn{5}{|l|}{ Histology } \\
\hline Well & $35(43.8)$ & $15(31.3)$ & $20(62.5)$ & \multirow[t]{3}{*}{0.0215} \\
\hline Moderately & $42(52.5)$ & $31(64.6)$ & II (34.4) & \\
\hline Poor & $3(3.8)$ & $2(4.2)$ & I (3.1) & \\
\hline \multicolumn{5}{|l|}{ pT } \\
\hline pTI & $3(3.8)$ & I (2.1) & $2(6.3)$ & \multirow[t]{4}{*}{0.3607} \\
\hline PT2 & $4(5.0)$ & $1(2.1)$ & $3(9.4)$ & \\
\hline PT3 & $65(81.3)$ & $41(85.4)$ & $24(75.0)$ & \\
\hline PT4 & $8(10.0)$ & $5(10.4)$ & $3(9.4)$ & \\
\hline \multicolumn{5}{|l|}{$p N$} \\
\hline Negative & $29(36.3)$ & II (22.9) & $18(56.3)$ & \multirow[t]{2}{*}{0.0024} \\
\hline Positive & $51(63.8)$ & $37(77.1)$ & $14(43.8)$ & \\
\hline \multicolumn{5}{|l|}{ Liver metastasis } \\
\hline Negative & 51 (63.8) & $28(58.3)$ & $23(71.9)$ & \multirow[t]{2}{*}{0.2171} \\
\hline Positive & $29(36.3)$ & $20(41.7)$ & $9(28.1)$ & \\
\hline \multicolumn{5}{|l|}{ pStage } \\
\hline 1 & $6(7.5)$ & $2(4.2)$ & $4(12.5)$ & \multirow[t]{5}{*}{0.3540} \\
\hline$\| \mathrm{A}$ & $22(27.5)$ & II (22.9) & II (34.4) & \\
\hline$\| B$ & $42(52.5)$ & $29(60.4)$ & $13(40.6)$ & \\
\hline III & $6(7.5)$ & $4(8.3)$ & $2(6.3)$ & \\
\hline IV & $4(5.0)$ & $2(4.2)$ & $2(6.3)$ & \\
\hline \multicolumn{5}{|c|}{ Lymphatic invasion } \\
\hline Negative & II (I3.8) & $2(4.2)$ & $9(28.1)$ & \multirow[t]{2}{*}{0.0023} \\
\hline Positive & $69(86.3)$ & $46(95.8)$ & $23(71.9)$ & \\
\hline \multicolumn{5}{|l|}{ Venous invasion } \\
\hline Negative & $19(23.8)$ & $9(18.8)$ & $10(31.3)$ & \multirow[t]{2}{*}{0.1981} \\
\hline Positive & $61(76.3)$ & $39(81.3)$ & $22(68.8)$ & \\
\hline
\end{tabular}

s.d. $=$ standard deviation.

Table 2 Correlation between expression of CDI33 and expression of VEGF-C and CXCR4 in pancreatic head carcinoma

\begin{tabular}{lccc}
\hline & \multicolumn{2}{c}{ CD I33 expression } & \\
\cline { 2 - 3 } & $\begin{array}{c}\text { Positive } \\
\text { expression } \\
\mathbf{n = 4 8}(\%)\end{array}$ & $\begin{array}{c}\text { Negative } \\
\text { expression } \\
\mathbf{n = 3 2}(\%)\end{array}$ & P-value \\
\hline VEGF-C expression & $13(27.1)$ & $22(68.8)$ & 0.0002 \\
$\quad \begin{array}{l}\text { Negative }(n=35) \\
\text { Positive }(n=45)\end{array}$ & $35(72.9)$ & $10(31.3)$ & \\
CXCR4 expression & & & \\
Negative $(n=12)$ & $8(16.7)$ & $4(12.5)$ & $0.609 \mid$ \\
Positive $(n=68)$ & $40(83.3)$ & $28(87.5)$ & \\
\hline
\end{tabular}

VEGF-C = vascular endothelial growth factor-C. 

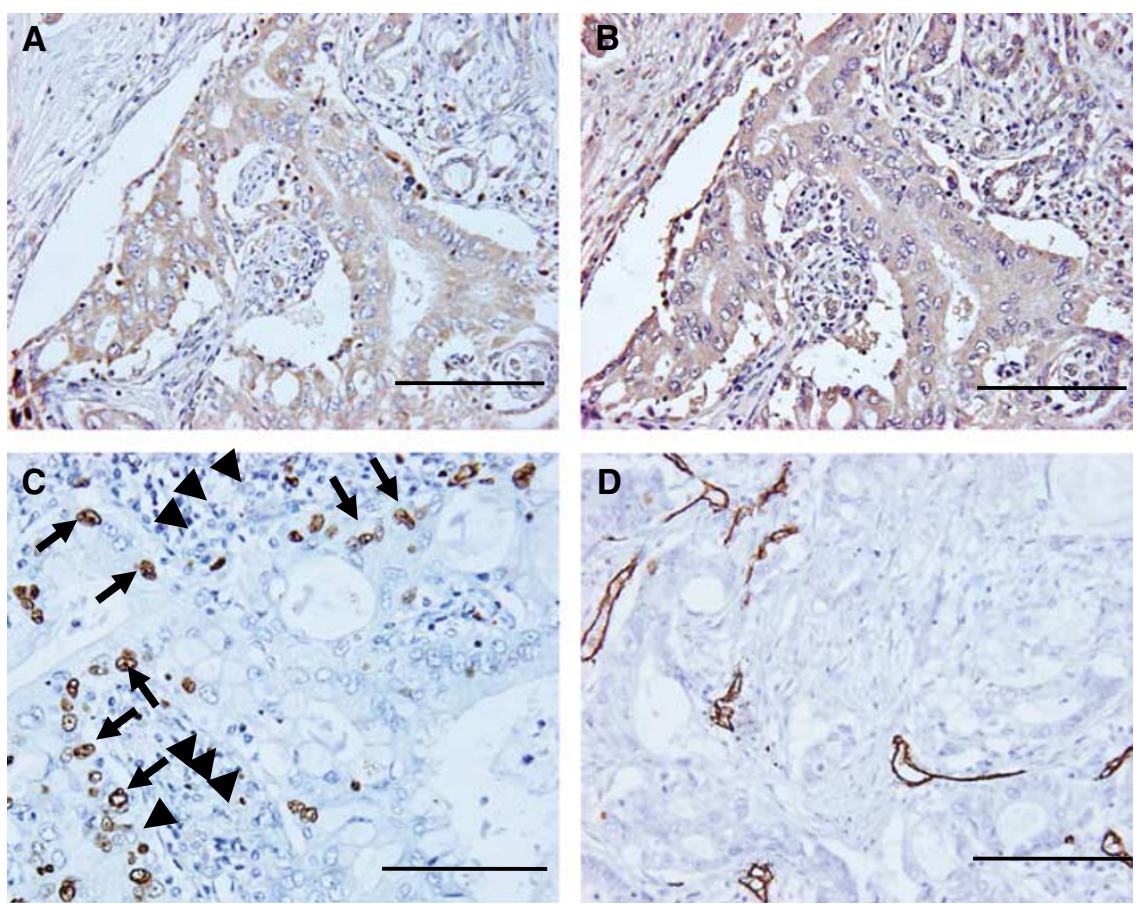

Figure 4 Immunohistochemical staining for VEGF-C, CXCR4, Ki-67, and CD34 in invasive ductal adenocarcinoma of the pancreas head. (A) Positive expression of VEGF-C was observed in the cytoplasm of all tumour cells. (B) Positive expression of CXCR4 was seen in all epithelial cells of adenocarcinoma. (C) Ki-67-positive expression was observed in the nuclei of certain CDI33-positive cells (arrows). Some CDI33-positive cells were negative for staining with Ki-67 (arrowheads). (D) Expression of CD34 was detected in microvessels. The sections shown in (A) and (B) are the consecutive slices of Figure IC, and those shown in (C) and (D) are the consecutive slices of Figure 2A. Scale bars, $100 \mu \mathrm{m}$.

Figure 4B, a typical pattern of CXCR4-positive expression is shown as an example in the consecutive slices of Figure 1C. The collective data indicate that CXCR4 expression was not associated with CD133 expression $(P=0.6091$; Table 2). Furthermore, in the CD133-positive group, there was no significant association between CXCR4 expression and lymph node metastasis $(P=0.4425)$ or lymphatic invasion $(P=0.5182)$.

\section{Relationship between CD133 and Ki-67 expression}

When the consecutive slices (of Figure 2A) were reacted with Ki-67 antibody demonstrating proliferating cells, some CD133-positive cells were reactive with $\mathrm{Ki}-67$ antibody (Figure 4C, arrows), but other cells were unreactive (Figure $4 \mathrm{C}$, arrowheads).

\section{Relationship between CD133 expression and MVD}

We next correlated expression of CD133 with density of microvessels in pancreatic cancers. Microvessels were delineated by staining with the CD34 antibody. In Figure 4D, tumour with MVD is shown as an example. Notably, MVD was significantly $(P=0.0467)$ higher in CD133-positive tumours (mean \pm s.d. $=$ $43.64 \pm 11.26)$ than in CD133-negative tumours (38.18 \pm 11.71 ; Figure 5).

\section{Prognostic impact of CD133 expression}

We examined a possible correlation between patient prognosis and the percentage of CD133-positive cells. The 5-year survival rate of patients with CD133-negative tumours was $23.5 \%$, that of patients with less than 5\% CD133-positive cells was $3.4 \%$, and that of patients with more than $5 \%$ CD133-positive cells was $0.0 \%$. This finding produced a significant difference in the 5-year survival rate between patients with tumours positive or negative for CD133

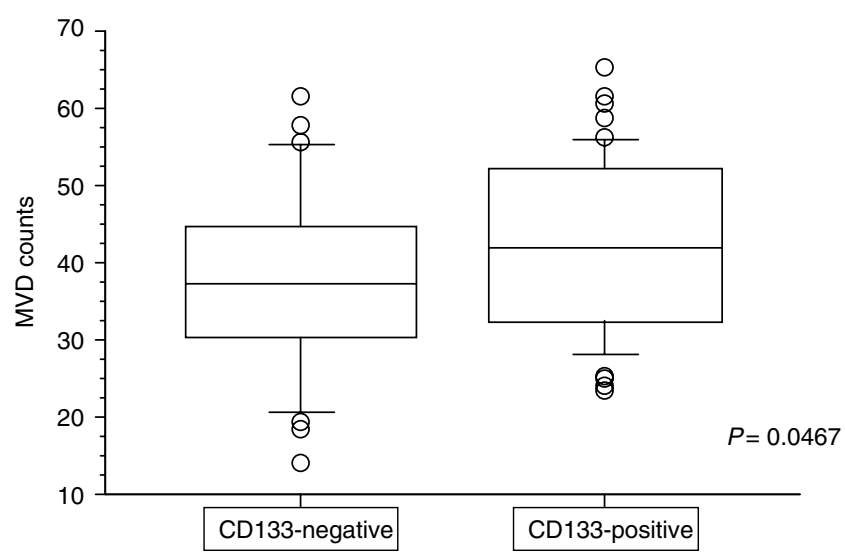

Figure 5 Microvessel density counts after observation of anti-CD34stained samples $\left(0.785 \mathrm{~mm}^{2}\right.$ per field) under a microscope with $\times 200$ power. The MVD (mean \pm s.d.) of the CDI33-positive specimens was significantly different from that of the CD/33-negative specimens (43.64 \pm | 1.26 vs $38.18 \pm$ | $1.71 ; P=0.0467$ ).

expression ( $P=0.0002$; Figure 6$)$, and between patients with more or less than $5 \%$ cells expressing CD133 ( $P=0.0366$; Figure 6$)$.

In the CD133-positive group, there was no significant difference in the 5-year survival rate between those patients who were positive or negative for CXCR4 expression ( $P=0.2176$; Figure 7$)$.

\section{Patient prognosis}

Tables 3 and 4 show the results of univariate and multivariate analyses relating to patient prognosis. Univariate analysis demonstrated that postoperative survival was significantly related to 


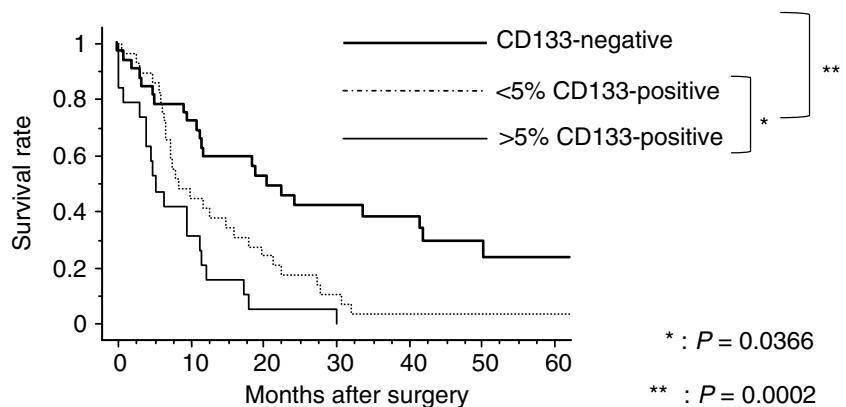

Figure 6 Kaplan-Meier survival curves for patients with more than 5\% CDI33-positive tumours, less than 5\% CDI33-positive tumours, and CDI33-negative tumours in the pancreatic head carcinomas. There was a significant difference in the 5 -year survival rate between patients with tumours that were positive and negative for CDI33 expression $(P=0.0002)$, and between patients with more and less than 5\% CDI33positive tumours $(P=0.0366)$.

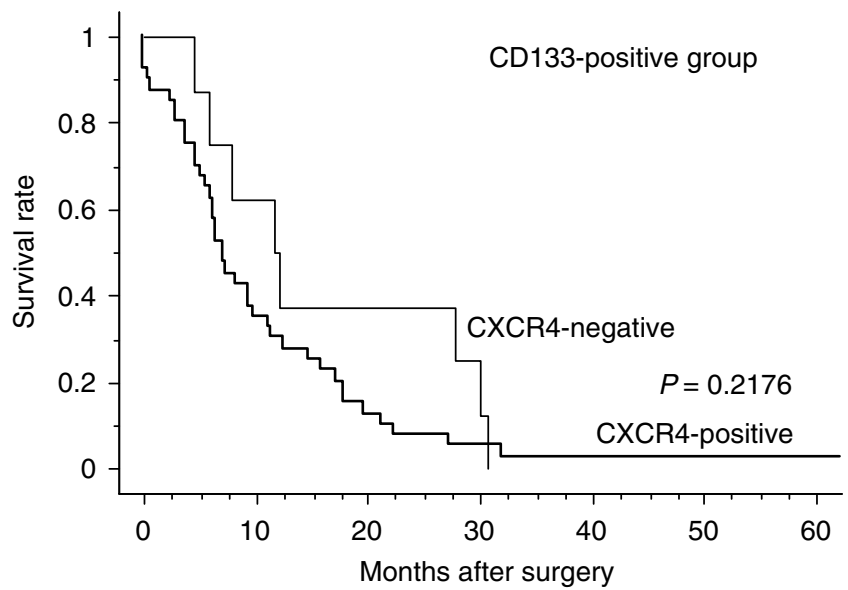

Figure 7 Kaplan-Meier survival curves for patients with CXCR4positive and CXCR4-negative tumours in the CDI33-positive group. There was no significant difference between the patients with tumours that were positive and negative for CXCR4 expression in the CDI33-positive group $(P=0.2176)$.

lymphatic invasion, lymph node metastasis, tumour depth, cancer stage, and $\mathrm{CD} 133$ expression $(P<0.05)$. Multivariate regression analysis found CD133 expression to be an independent prognostic factor, but lymph node metastasis and tumour depth were not.

\section{DISCUSSION}

Recently, it was hypothesised that tumours comprise heterogeneous populations of cells that differ in their abilities to proliferate and exhibit self-renewal. Only a small number of cells, so-called CSCs, can proliferate and exhibit extensive self-renewal; most tumour cells have a limited ability to do so and tend to differentiate into cells that form the tumour mass (Reya et al, 2001; Presnell et al, 2002; Pardal et al, 2003). Cancer stem cells appear to be able to initiate and drive tumour growth in different haematological and solid tumours. CD133, a recently reported prospective marker for CSC, is expressed in a variety of tumours. However, to our knowledge, no attempt has been made to detect CD133 expression in pancreatic cancer specimens.

In this study, we used immunohistochemical staining to detect positive expression of $\mathrm{CD} 133$ in $60 \%$ of 80 pancreatic head
Table 3 Univariate analysis of prognostic factors in pancreatic head carcinoma

\begin{tabular}{|c|c|c|c|}
\hline Variables & $n$ & 5 -year survival rate $(\%)$ & $P$-value \\
\hline \multicolumn{4}{|l|}{ Age (years) } \\
\hline Over 65 & 47 & 10.4 & \multirow[t]{2}{*}{0.4232} \\
\hline Under 64 & 33 & 9.6 & \\
\hline \multicolumn{4}{|l|}{ Gender } \\
\hline Male & 52 & 10.6 & \multirow{2}{*}{0.9762} \\
\hline Female & 28 & 0.0 & \\
\hline \multicolumn{4}{|l|}{ pT } \\
\hline pTI, 2 & 7 & 42.9 & \multirow[t]{2}{*}{0.0417} \\
\hline $\mathrm{pT} 3,4$ & 73 & 5.9 & \\
\hline \multicolumn{4}{|l|}{$p N$} \\
\hline Negative & 29 & 20.4 & \multirow[t]{2}{*}{0.0056} \\
\hline Positive & 51 & 3.2 & \\
\hline \multicolumn{4}{|c|}{ Liver metastasis } \\
\hline Negative & 51 & 14.2 & \multirow[t]{2}{*}{0.0797} \\
\hline Positive & 29 & 3.4 & \\
\hline \multicolumn{4}{|l|}{ pStage } \\
\hline I, II & 70 & 11.6 & \multirow[t]{2}{*}{0.0073} \\
\hline III, IV & 10 & 0.0 & \\
\hline \multicolumn{4}{|c|}{ Lymphatic invasion } \\
\hline Negative & 11 & 30.7 & \multirow[t]{2}{*}{0.0334} \\
\hline Positive & 69 & 6.9 & \\
\hline \multicolumn{4}{|c|}{ Venous invasion } \\
\hline Negative & 19 & 15.8 & \multirow[t]{2}{*}{0.4944} \\
\hline Positive & 61 & 7.3 & \\
\hline \multicolumn{4}{|c|}{ CD/33 expression } \\
\hline Negative & 32 & 23.5 & \multirow[t]{2}{*}{0.0002} \\
\hline Positive & 48 & 2.1 & \\
\hline
\end{tabular}

Table 4 Multivariate analyses of prognostic factors in pancreatic head carcinoma

\begin{tabular}{lcccc}
\hline $\begin{array}{l}\text { Independent } \\
\text { factors }\end{array}$ & $\begin{array}{c}\text { Univariate } \\
\boldsymbol{P}\end{array}$ & $\begin{array}{c}\text { Multivariate } \\
\boldsymbol{P}\end{array}$ & $\begin{array}{c}\text { Hazard } \\
\text { ratio }\end{array}$ & $\begin{array}{c}\mathbf{9 5 \%} \\
\text { confidence } \\
\text { interval }\end{array}$ \\
\hline $\mathrm{pT}^{\mathrm{N}} \mathrm{PTI}, 2 / \mathrm{pT} 3,4$ & 0.0417 & 0.5701 & 1.355 & $0.475-3.823$ \\
$\mathrm{pN}$ & & & & \\
$\quad$ Negative/positive & 0.0056 & 0.2141 & 1.434 & $0.812-2.534$ \\
$\begin{array}{c}\text { CD/33 expression } \\
\text { Negative/positive }\end{array}$ & 0.0002 & 0.0090 & 2.151 & $1.211-3.869$ \\
\hline
\end{tabular}

carcinoma specimens, and found that the percentage of CD133positive cells per specimen was less than $15 \%$. These data are in agreement with the finding that CSCs represent only a very small portion of the total tumour cell population. For example, CD133positive cells were detected in 0.7-6.1\% (Ricci-Vitiani et al, 2007), $1.8-24.5 \%$ (O’Brien et al, 2007), 0.3-3\% (Todaro et al, 2007) of primary colon cancer cells, and in $0.7-3.2 \%$ of primary pancreatic cancer cells using flow cytometric analysis (Hermann et al, 2007). Immunohistochemical staining revealed CD133 expression in $1-3 \%$ of hepatocellular carcinoma specimens (Ma et al, 2007). Notably, we observed no staining for CD133 in normal pancreatic ductal epithelium in the present study (Figure 1A). The present 
immunohistochemical data appear to support the hypothesis that CD133-positive pancreatic carcinoma cells are involved in the tumorigenic process.

We found that CD133 expression was significantly associated with histological type, lymphatic invasion, and lymph node metastasis (Table 1). It is noteworthy that lymph node metastasis and lymphatic invasion are correlated with CD133 expression, as a recent study demonstrated that a melanoma cell line highly enriched with CD133-expressing cells concomitantly expresses lymphoangiogenic markers, vascular endothelial growth factor receptor (VEGFR)-3 and lymphatic vessel endothelial hyaluronan receptor (LYVE)-1 (Monzani et al, 2007). As possible correlation between VEGF-C expression and lymphangiogenesis has previously been described (Kurahara et al, 2004; Mohammed et al, 2007), we examined VEGF-C expression in pancreatic cancer specimens and found it to be significantly associated with CD133 expression (Table 2). This suggests that CD133-positive pancreatic carcinoma cells promote lymphatic metastasis not only by inducing lymphangiogenesis, but also by facilitating self-entry into the lymphatic system. In view of the potential link to lymphangiogenesis, further studies are needed to address the possible role of CD133 in lymph node metastasis of pancreatic cancers.

Recently, the niche microenvironments of CSCs in brain tumours have been shown to be important for maintaining and self-renewing CSCs through close interaction with endothelial cells (Calabrese et al, 2007). In this study, we could not reveal the histological site of such niches, although we observed that CD133positive cells were localised in the peripheral site (facing interstitial space) of adenocarcinoma glandular structures, and did not express the epithelial differentiation marker CK (Hermann et al, 2007). Considering the relationship between CD133-positive cells and lymph node metastasis, lymphangiogenesis and/or lymphatic vessels might be involved in forming the niche microenvironments of CSCs for pancreatic cancer. An understanding of niche histological sites would therefore be of use in preventing progression of pancreatic cancer cells.

High-grade MVD was more frequently found in CD133-positive tumours (Figure 5), reflecting a possible effect of CD133 on tumour vascularity in pancreatic cancer. Bao et al (2006b) made similar observations that CD133-positive tumour cells were more vascular than CD133-negative ones. In this context, investigations are currently underway to examine whether CD133-positive cells established from primary pancreatic carcinomas express VEGF more strongly than CD133-negative cells. There is a clear difference between CD133-positive and CD133-negative cells derived from pancreatic cancer regarding angiogenic potential.

\section{REFERENCES}

Abraham BK, Fritz P, McClellan M, Hauptvogel P, Athelogou M, Brauch H (2005) Prevalence of CD $44^{+} / \mathrm{CD} 24^{-/ \text {low }}$ cells in breast cancer may not be associated with clinical outcome but may favor distant metastasis. Clin Cancer Res 11: 1154-1159

Al-Hajj M, Wicha MS, Benito-Hernandez A, Morrison SJ, Clarke MF (2003) Prospective identification of tumorigenic breast cancer cells. Proc Natl Acad Sci USA 100: 3983-3988

Bao S, Wu Q, McLendon RE, Hao Y, Shi Q, Hjelmeland AB, Dewhirst MW, Bigner DD, Rich JN (2006a) Glioma stem cells promote radioresistance by preferential activation of the DNA damage response. Nature 444: $756-760$

Bao S, Wu Q, Sathornsumetee S, Hao Y, Li Z, Hjelmeland AB, Shi Q, McLendon RE, Bigner DD, Rich JN (2006b) Stem cell-like glioma cells promote tumor angiogenesis through vascular endothelial growth factor. Cancer Res 66: 7843-7848

Beier D, Hau P, Proescholdt M, Lohmeier A, Wischhusen J, Oefner PJ, Aigner L, Brawanski A, Bogdahn U, Beier CP (2007) CD133(+) and
A specific subpopulation of $\mathrm{CD}_{133}{ }^{+} \mathrm{CXCR}^{+}$CSCs was recently identified as being responsible for tumour metastasis (Hermann et al, 2007). The CXCR4 protein has multiple essential functions, including homing of stem cells and metastasis of cancer cells (Miki et al, 2007). Several cancers express CXCR4, and a relationship between CXCR4 expression and malignant potentiality has been suggested (Muller et al, 2001; Kaifi et al, 2005). In the present study, $85 \%$ of specimens exhibited positive expression of CXCR4. Notably, positive expression of CXCR4 was observed in all epithelial cells of adenocarcinoma, which is consistent with previous observations (Gockel et al, 2006). Furthermore, there was no significant association between CXCR4 expression and lymph node metastasis, lymphatic invasion, together with prognosis in the CD133-positive group. Taking these findings into consideration, it appears that CXCR4 expression is not associated with CD133 expression, nor with other cancer-related events in the CD133-positive group.

It remains to be determined whether CD133-positive cancer cells exhibit higher degrees of proliferative activity than CD133-negative ones. As a preliminary test, we assessed this possibility using Ki-67 antibody staining and observed the presence of both highly proliferative activity and less proliferative activity of CD133positive cells. To confirm these findings, we are currently examining the MIB-1 labelling index in CD133-positive and CD133-negative cells.

In conclusion, our immunohistochemical results indicate that CD133 expression in pancreatic head cancer is associated with histological type, lymphatic invasion, lymph node metastasis, VEGF-C expression, and prognosis. Multivariate survival analysis revealed that $\mathrm{CD} 133$ expression is an independent prognostic factor. These results suggest that CD133 expression is a useful marker for predicting the outcome of patients with pancreatic cancer. This is the first report of an association between CD133 expression and pancreatic cancer. Understanding the biological function of CD133 expression as a CSC marker in pancreatic cancer will be helpful in elucidating its role in the pathogenesis of pancreatic cancer and developing more effective therapeutic approaches.

\section{ACKNOWLEDGEMENTS}

We thank our laboratory assistants for their technical support. This study was supported in part by grants-in-aid for scientific research from the Ministry of Education, Science, Sports, and Culture, Japan.
CD133(-) glioblastoma-derived cancer stem cells show differential growth characteristics and molecular profiles. Cancer Res 67: 4010-4015 Bonnet D, Dick JE (1997) Human acute myeloid leukemia is organized as a hierarchy that originates from a primitive hematopoietic cell. Nat Med 3: $730-737$

Calabrese C, Poppleton H, Kocak M, Hogg TL, Fuller C, Hamner B, Oh EY, Gaber MW, Finklestein D, Allen M, Frank A, Bayazitov IT, Zakharenko SS, Gajjar A, Davidoff A, Gilbertson RJ (2007) A perivascular niche for brain tumor stem cells. Cancer Cell 11: 69-82

Collins AT, Berry PA, Hyde C, Stower MJ, Maitland NJ (2005) Prospective identification of tumorigenic prostate cancer stem cells. Cancer Res 65: $10946-10951$

Corbeil D, Roper K, Hellwig A, Tavian M, Miraglia S, Watt SM, Simmons PJ, Peault B, Buck DW, Huttner WB (2000) The human AC133 hematopoietic stem cell antigen is also expressed in epithelial cells and targeted to plasma membrane protrusions. J Biol Chem 275: $5512-5520$ 
Dalerba P, Dylla SJ, Park IK, Liu R, Wang X, Cho RW, Hoey T, Gurney A, Huang EH, Simeone DM, Shelton AA, Parmiani G, Castelli C, Clarke MF (2007) Phenotypic characterization of human colorectal cancer stem cells. Proc Natl Acad Sci USA 104: 10158-10163

Ferrandina G, Bonanno G, Pierelli L, Perillo A, Procoli A, Mariotti A, Corallo M, Martinelli E, Rutella S, Paglia A, Zannoni G, Mancuso S, Scambia G (2007) Expression of CD133-1 and CD133-2 in ovarian cancer. Int J Gynecol Cancer Published online, 14 September

Florek M, Haase M, Marzesco AM, Freund D, Ehninger G, Huttner WB, Corbeil D (2005) Prominin-1/CD133, a neural and hematopoietic stem cell marker, is expressed in adult human differentiated cells and certain types of kidney cancer. Cell Tissue Res 319: 15-26

Gockel I, Schimanski CC, Heinrich C, Wehler T, Frerichs K, Drescher D, von Langsdorff C, Domeyer M, Biesterfeld S, Galle PR, Junginger T, Moehler M (2006) Expression of chemokine receptor CXCR4 in esophageal squamous cell and adenocarcinoma. BMC Cancer 6: 290

Hermann PC, Huber SL, Herrler T, Aicher A, Ellwart JW, Guba M, Bruns CJ, Heeschen C (2007) Distinct populations of cancer stem cells determine tumor growth and metastatic activity in human pancreatic cancer. Cell Stem Cell 1: 313-323

Horn PA, Tesch H, Staib P, Kube D, Diehl V, Voliotis D (1999) Expression of AC133, a novel hematopoietic precursor antigen, on acute myeloid leukemia cells. Blood 93: 1435-1437

Hsu SM, Raine L, Fanger H (1981) Use of avidin-biotin-peroxidase complex $(\mathrm{ABC})$ in immunoperoxidase techniques: a comparison between $\mathrm{ABC}$ and unlabeled antibody (PAP) procedures. J Histochem Cytochem 29: $577-580$

Ieta K, Tanaka F, Haraguchi N, Kita Y, Sakashita H, Mimori K, Matsumoto $\mathrm{T}$, Inoue $\mathrm{H}$, Kuwano $\mathrm{H}$, Mori $\mathrm{M}$ (2007) Biological and genetic characteristics of tumor-initiating cells in colon cancer. Ann Surg Oncol 15: $638-648$

Igarashi N, Takahashi M, Ohkubo H, Omata K, Iida R, Fujimoto S (1999) Predictive value of Ki-67, p53 protein, and DNA content in the diagnosis of gastric carcinoma. Cancer 86: 1449-1454

Kaifi JT, Yekebas EF, Schurr P, Obonyo D, Wachowiak R, Busch P, Heinecke A, Pantel K, Izbicki JR (2005) Tumor-cell homing to lymph nodes and bone marrow and CXCR4 expression in esophageal cancer. J Natl Cancer Inst 97: 1840-1847

Klein WM, Wu BP, Zhao S, Wu H, Klein-Szanto AJ, Tahan SR (2007) Increased expression of stem cell markers in malignant melanoma. Mod Pathol 20: 102-107

Kurahara H, Takao S, Maemura K, Shinchi H, Natsugoe S, Aikou T (2004) Impact of vascular endothelial growth factor-C and -D expression in human pancreatic cancer: its relationship to lymph node metastasis. Clin Cancer Res 10: $8413-8420$

Kurahara H, Takao S, Maemura K, Shinchi H, Natsugoe S, Aikou T (2007) Impact of lymph node micrometastasis in patients with pancreatic head cancer. World J Surg 31: 483-490

Li C, Heidt DG, Dalerba P, Burant CF, Zhang L, Adsay V, Wicha M, Clarke MF, Simeone DM (2007) Identification of pancreatic cancer stem cells. Cancer Res 67: 1030-1037

Lin EH, Hassan M, Li Y, Zhao H, Nooka A, Sorenson E, Xie K, Champlin R, Wu X, Li D (2007) Elevated circulating endothelial progenitor marker CD133 messenger RNA levels predict colon cancer recurrence. Cancer 110: $534-542$

Ma S, Chan KW, Hu L, Lee TK, Wo JY, Ng IO, Zheng BJ, Guan XY (2007) Identification and characterization of tumorigenic liver cancer stem/ progenitor cells. Gastroenterology 132: $2542-2556$

Maeda S, Shinchi H, Kurahara H, Mataki Y, Noma H, Maemura K, Aridome K, Yokomine T, Natsugoe S, Aikou T, Takao S (2007) Clinical significance of midkine expression in pancreatic head carcinoma. $\mathrm{Br} J$ Cancer 97: 405-411

Mehra N, Penning M, Maas J, Beerepoot LV, van Daal N, van Gils CH, Giles RH, Voest EE (2006) Progenitor marker CD133 mRNA is elevated in peripheral blood of cancer patients with bone metastases. Clin Cancer Res 12: $4859-4866$

Miki J, Furusato B, Li H, Gu Y, Takahashi H, Egawa S, Sesterhenn IA, McLeod DG, Srivastava S, Rhim JS (2007) Identification of putative stem cell markers, CD133 and CXCR4, in hTERT-immortalized primary nonmalignant and malignant tumor-derived human prostate epithelial cell lines and in prostate cancer specimens. Cancer Res 67: $3153-3161$

Miraglia S, Godfrey W, Yin AH, Atkins K, Warnke R, Holden JT, Bray RA, Waller EK, Buck DW (1997) A novel five-transmembrane hematopoietic stem cell antigen: isolation, characterization, and molecular cloning. Blood 90: 5013-5021

Mohammed RA, Green A, El-Shikh S, Paish EC, Ellis IO, Martin SG (2007) Prognostic significance of vascular endothelial cell growth factors -A, -C and -D in breast cancer and their relationship with angio- and lymphangiogenesis. Br J Cancer 96: 1092 - 1100

Monzani E, Facchetti F, Galmozzi E, Corsini E, Benetti A, Cavazzin C, Gritti A, Piccinini A, Porro D, Santinami M, Invernici G, Parati E, Alessandri G, La Porta CA (2007) Melanoma contains CD133 and ABCG2 positive cells with enhanced tumourigenic potential. Eur J Cancer 43: 935-946

Muller A, Homey B, Soto H, Ge N, Catron D, Buchanan ME, McClanahan T, Murphy E, Yuan W, Wagner SN, Barrera JL, Mohar A, Verastegui E, Zlotnik A (2001) Involvement of chemokine receptors in breast cancer metastasis. Nature 410: $50-56$

Neuzil J, Stantic M, Zobalova R, Chladova J, Wang X, Prochazka L, Dong L, Andera L, Ralph SJ (2007) Tumour-initiating cells $v s$ cancer 'stem' cells and CD133: what's in the name? Biochem Biophys Res Commun 355: $855-859$

O'Brien CA, Pollett A, Gallinger S, Dick JE (2007) A human colon cancer cell capable of initiating tumour growth in immunodeficient mice. Nature 445: $106-110$

Olempska M, Eisenach PA, Ammerpohl O, Ungefroren H, Fandrich F, Kalthoff H (2007) Detection of tumor stem cell markers in pancreatic carcinoma cell lines. Hepatobiliary Pancreat Dis Int 6: 92-97

Pardal R, Clarke MF, Morrison SJ (2003) Applying the principles of stem-cell biology to cancer. Nat Rev Cancer 3: 895-902

Pasquinelli G, Preda P, Martinelli GN, Galassi A, Santini D, Venza E (1995) Filamentous inclusions in nonneoplastic and neoplastic pancreas: an ultrastructural and immunogold labeling study. Ultrastruct Pathol 19: 495-500

Patrawala L, Calhoun-Davis T, Schneider-Broussard R, Tang DG (2007) Hierarchical organization of prostate cancer cells in xenograft tumors: the $\mathrm{CD} 44^{+} \alpha 2 \beta 1^{+}$cell population is enriched in tumor-initiating cells. Cancer Res 67: 6796-6805

Ponti D, Costa A, Zaffaroni N, Pratesi G, Petrangolini G, Coradini D, Pilotti S, Pierotti MA, Daidone MG (2005) Isolation and in vitro propagation of tumorigenic breast cancer cells with stem/progenitor cell properties. Cancer Res 65: 5506-5511

Presnell SC, Petersen B, Heidaran M (2002) Stem cells in adult tissues. Semin Cell Dev Biol 13: 369-376

Prince ME, Sivanandan R, Kaczorowski A, Wolf GT, Kaplan MJ, Dalerba P, Weissman IL, Clarke MF, Ailles LE (2007) Identification of a subpopulation of cells with cancer stem cell properties in head and neck squamous cell carcinoma. Proc Natl Acad Sci USA 104: 973-978

Reya T, Morrison SJ, Clarke MF, Weissman IL (2001) Stem cells, cancer, and cancer stem cells. Nature 414: 105-111

Ricci-Vitiani L, Lombardi DG, Pilozzi E, Biffoni M, Todaro M, Peschle C, De Maria R (2007) Identification and expansion of human colon-cancerinitiating cells. Nature 445: 111-115

Richardson GD, Robson CN, Lang SH, Neal DE, Maitland NJ, Collins AT (2004) CD133, a novel marker for human prostatic epithelial stem cells. J Cell Sci 117: 3539-3545

Shmelkov SV, St Clair R, Lyden D, Rafii S (2005) AC133/CD133/Prominin1. Int J Biochem Cell Biol 37: 715-719

Silverberg E, Lubera JA (1988) Cancer statistics, 1988. CA Cancer J Clin 38: $5-22$

Singh SK, Clarke ID, Terasaki M, Bonn VE, Hawkins C, Squire J, Dirks PB (2003) Identification of a cancer stem cell in human brain tumors. Cancer Res 63: 5821-5828

Singh SK, Hawkins C, Clarke ID, Squire JA, Bayani J, Hide T, Henkelman RM, Cusimano MD, Dirks PB (2004) Identification of human brain tumour initiating cells. Nature 432: 396-401

Sobin LH, Wittekind CH (2002) International Union Against Cancer. TNM Classification of Malignant Tumours, 6th edn. Wiley-Liss: New York

Suetsugu A, Nagaki M, Aoki H, Motohashi T, Kunisada T, Moriwaki H (2006) Characterization of CD133+ hepatocellular carcinoma cells as cancer stem/progenitor cells. Biochem Biophys Res Commun 351: $820-824$

Todaro M, Alea MP, Di Stefano AB, Cammareri P, Vermeulen L, Iovino F, Tripodo C, Russo A, Gulotta G, Medema JP, Stassi G (2007) Colon cancer stem cells dictate tumor growth and resist cell death by production of interleukin-4. Cell Stem Cell 1: 389-402 
Weidner N, Semple JP, Welch WR, Folkman J (1991) Tumor angiogenesis and metastasis - correlation in invasive breast carcinoma. $N$ Engl J Med 324: $1-8$

Weigmann A, Corbeil D, Hellwig A, Huttner WB (1997) Prominin, a novel microvilli-specific polytopic membrane protein of the apical surface of epithelial cells, is targeted to plasmalemmal protrusions of non-epithelial cells. Proc Natl Acad Sci USA 94: 12425-12430
Yin AH, Miraglia S, Zanjani ED, Almeida-Porada G, Ogawa M, Leary AG, Olweus J, Kearney J, Buck DW (1997) AC133, a novel marker for human hematopoietic stem and progenitor cells. Blood 90: 5002-5012

Yin S, Li J, Hu C, Chen X, Yao M, Yan M, Jiang G, Ge C, Xie H, Wan D, Yang S, Zheng S, Gu J (2007) CD133 positive hepatocellular carcinoma cells possess high capacity for tumorigenicity. Int J Cancer 120: $1444-1450$ 